\title{
Magnetic polarity stratigraphy and paleolatitude of the Triassic-Jurassic Blomidon Formation in the Fundy basin (Canada): implications for early Mesozoic tropical climate gradients
}

\author{
Dennis V. Kent ${ }^{\mathrm{a}, \mathrm{b}, *}$, Paul E. Olsen ${ }^{\mathrm{b}}$ \\ a Department of Geological Sciences, Rutgers University, Piscataway, NJ 08854, USA \\ b Lamont-Doherty Earth Observatory, Palisades, NY 10964, USA
}

Received 20 January 2000; received in revised form 7 April 2000; accepted 9 April 2000

\begin{abstract}
A magnetic polarity stratigraphy is established for a continuously cored $360 \mathrm{~m}$ thick section of the entire cyclical lacustrine sequence and part of the sandy fluvial and eolian basal sequence of the Late Triassic Blomidon Formation in the Fundy basin in Nova Scotia (Canada). In conjunction with published results for the Newark and Dan River basins, the Fundy basin record allows us to precisely map the spatio-temporal distribution of climate-sensitive continental lithofacies along a paleolatitudinal transect in eastern North America corresponding to the tropics of Pangea in the Late Triassic. Indicators of high humidity such as coals and black shales tend to occur within $5^{\circ}$ of the paleoequator and eolian dunes and other evidence of aridity occurs within $10^{\circ}$ of the paleoequator. Although steep, the latitudinal climate gradient in the interior of the Pangea supercontinent is not that different from the average modern zonal variation in the balance of evaporation to precipitation even though the distribution of continents was radically different and there is no evidence of continental ice sheets in the Late Triassic. We suggest that the common perception of a dry paleoequator in the Triassic is largely an artifact of observational bias because compilations of paleoclimate proxies usually have spatiotemporal resolutions that are inadequate to delineate narrow zonal climate belts, giving an aliased impression of ancient climate. (C) 2000 Elsevier Science B.V. All rights reserved.
\end{abstract}

Keywords: Triassic; paleoclimatology; magnetostratigraphy; paleolatitude; Minas Basin

\section{Introduction}

The early Mesozoic, particularly the Triassic, is usually regarded as being warm and arid with

\footnotetext{
* Corresponding author. Tel.: +1-914-365-8544;

Fax: +1-914-365-8158; E-mail: dvk@1deo.columbia.edu
}

virtually no evidence of polar ice sheets [1,2]. Indeed, Wilson et al. [3] characterized the Triassic as perhaps the most arid period of the Phanerozoic, citing evidence for widespread deposition of evaporites at low- to mid-latitudes and the relative ubiquity of similarly distributed redbeds and eolian deposits. Monsoonal atmospheric circulation has been suggested to have dominated the Triassic climate of Pangea to account for an apparently 


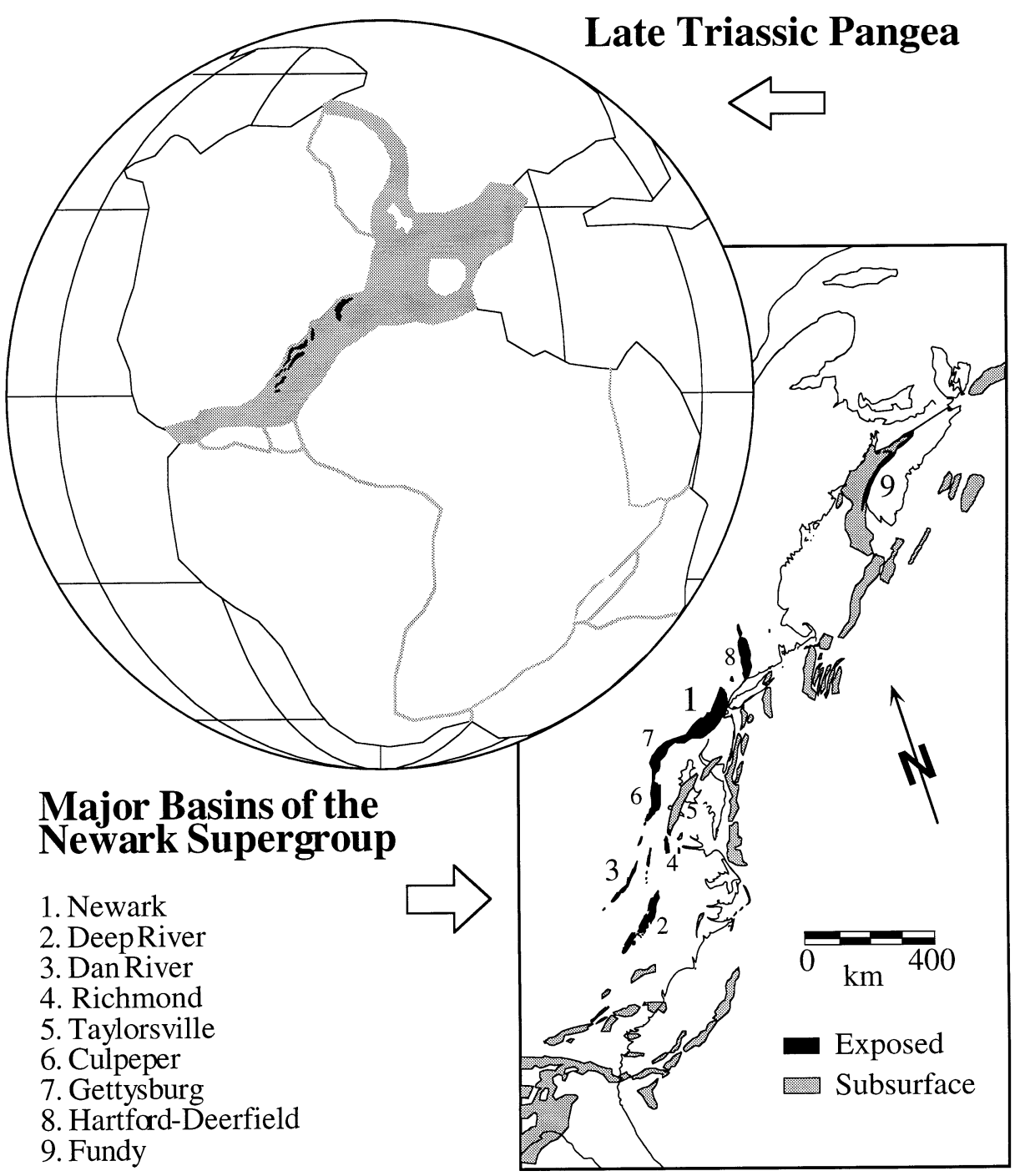

Fig. 1. (a) Mesozoic rifting within the supercontinent of Pangea positioned according to a mean Late Triassic paleopole for cratonic North America [41]. (b) Major early Mesozoic rift basins in eastern North America, including the Dan River, Newark and Fundy basins discussed here.

dry equatorial belt $[4,5]$ and the apparent expansion of deserts in the Triassic and Early Jurassic to an extent not since repeated [6]. These features of a hothouse world that are so very different from our own have challenged climate modeling efforts [7].

The Newark rift basins of eastern North America, which developed in the central part of the fragmenting supercontinent of Pangea in the early Mesozoic (Fig. 1), contain a unique record of continental tropical climate [8]. Strong evidence of aridity in the northern rift basins is given by the discovery of eolian deposits [9], the presence of sand patch fabrics and evaporites, and the absence of organic-rich shales in much of the Fundy basin section [10,11]. The arid depositional environments in the Fundy basin section contrast with the presence of coals and other indicators of high humidity in the Dan River and other southern rift basins [11]. The regional distribution of such cli- 


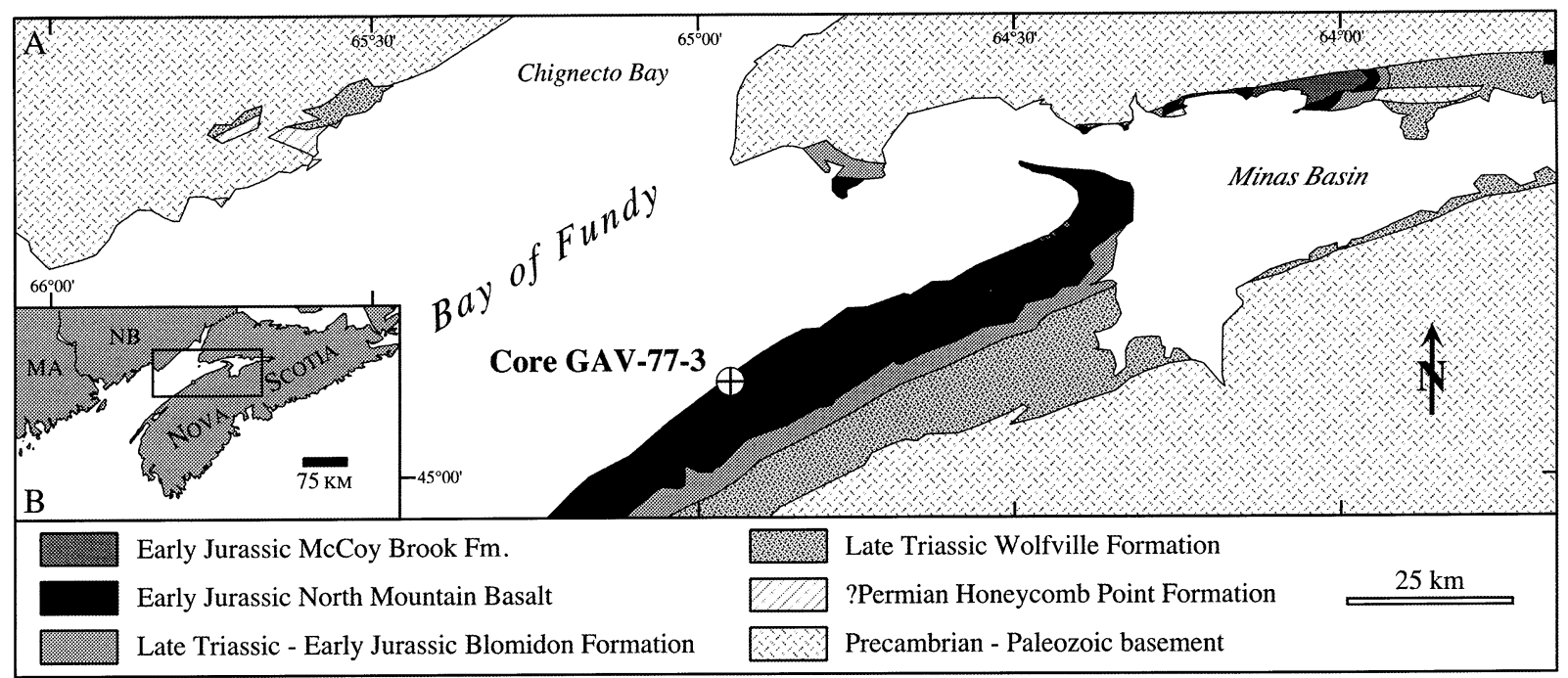

Fig. 2. The Fundy basin in the Canadian Maritimes showing the outcrop pattern for the Fundy basin section and the location of the GAV-77-3 drill core. Position of the map in A shown in rectangle in inset B.

mate-sensitive rocks may have been strongly influenced by non-zonal monsoonal and orographic climate patterns $[3-5,12,13]$. Alternatively, the climate-sensitive rocks reflect a steep zonal northsouth tropical climatic gradient $[9,11]$, an attractive hypothesis because of the simplicity and specificity of predictions that can be tested. Diagnostic tests, however, place stringent demands on the spatio-temporal resolution of climate recorders as well as independent paleolatitudinal control. This is because the drift of North America across latitudinal belts needs to be considered given the long duration ( $30 \mathrm{Myr}$; [14]) of the Late Triassic. Moreover, aliasing of paleoclimate patterns can result from miscorrelation of isolated and geographically dispersed sections of continental rock.

We attempt to gauge the applicability of a zonal climate in the tropics of Pangea during the Late Triassic by (1) precisely correlating the Fundy basin section with sequences of climatesensitive rocks from the more southerly rift basins in eastern North America by using magnetic polarity stratigraphy, and (2) placing these widely separated $(\sim 1000 \mathrm{~km})$ continental deposits in an independent paleolatitudinal framework based on paleomagnetic inclinations. We have already established a diagnostic magnetic polarity stratig- raphy and paleolatitudes of deposition for the several thousand $m$ thick Newark and Dan River basin sections $[15,16]$. Here we report the paleomagnetism of more than $300 \mathrm{~m}$ of Late Triassic continental sediments recovered in a drill core in the Fundy basin. These data enable us to evaluate the gradient of climate-sensitive rocks of tropical Pangea in the Late Triassic and to compare it to modern zonal gradients in climate parameters.

\section{Geological setting of the Fundy basin}

The Fundy basin of Nova Scotia and New Brunswick, Canada, is the most northerly and one of the largest of the exposed early Mesozoic rift basins of eastern North America (Fig. 2). The basin fill is divided into four formations [10]: the basal mainly fluvial Wolfville Formation (Fm.) that unconformably overlies Carboniferous and older rocks; above it the cyclical largely lacustrine Blomidon Fm. of Late Triassic to earliest Jurassic age; the overlying lavas of the North Mountain Basalt, and at the top, the fluvio-lacustrine rocks of the McCoy Brook Fm. (including the Scots Bay Member) of Early Jurassic age, complete the preserved rift basin sequence. The cumulative thickness of the exposed strata is only about $1 \mathrm{~km}$ 
although the total thickness beneath the Bay of Fundy may be greater than $4 \mathrm{~km}$ [17]. Eolian sandstones of the Red Head Member occur in the basal Blomidon Fm. $[9,18,19]$ and are of Norian age on the basis of a vertebrate fauna [20] and tectonostratigraphic considerations [8]. The palynological Triassic/Jurassic boundary occurs in the uppermost Blomidon Fm., just a few meters below the North Mountain Basalt [21]. Zircons from the North Mountain Basalt produced $\mathrm{U} / \mathrm{Pb}$ dates of $202 \pm 1 \mathrm{Ma}$ which give important age constraints on the Triassic/Jurassic boundary [22].

Dramatic exposures of the Fundy basin section occur along the north shore of Nova Scotia, although a complete section of the gently dipping beds would have to be assembled from faultbounded blocks. The continuous sampling that is required for magnetostratigraphic and cycle stratigraphic analyses is made further problematical by dissolution of evaporites on the cliff exposures. Previous paleomagnetic work on the Fundy basin sedimentary section was based on outcrop sampling and was not designed to produce a detailed magnetostratigraphy [23]. Fortunately, we had access to a continuously cored section which provided a complete section of the cyclical as well as the basal fluvial and eolian (Red Head Member) parts of the Blomidon Fm. for detailed stratigraphic study.

\section{GAV-77-3 drill core}

The Getty Mines GAV-77-3 drill core $($ Lat $=$ $45^{\circ} 5^{\prime} 38^{\prime \prime} \mathrm{N}$, Lon $=64^{\circ} 58^{\prime} 35^{\prime \prime} \mathrm{W}$ ) was spudded on North Mountain Basalt on the Nova Scotia shore of the Bay of Fundy (Fig. 2). A total of approximately $570 \mathrm{~m}$ of section was recovered, including $\sim 210 \mathrm{~m}$ of North Mountain Basalt and $\sim 360 \mathrm{~m}$ representing the entire cyclical part of the Blomidon and the fluvial and eolian basal part of the formation (Red Head Member; [19]). The $3.5 \mathrm{~cm}$ diameter core is stored at Acadia University where it was made available to us for description and sampling. The core was not oriented in azimuth but is assumed to have penetrated vertically into nearly flat-lying beds as suggested by projec- tion of regional stratal geometry indicating a $\sim 2^{\circ}$ northerly dip [24] and by the lack of discernible systematic apparent dip in bedding-core intersections. A total of 183 half-round samples from the cyclical part of the Blomidon Fm. and three samples from the North Mountain Basalt were analyzed for paleomagnetism. (We also took 16 reconnaissance samples from the sandier lithologies near the base of the core but they did not yield satisfactory results and are not considered further.) The up-core orientation was marked on the samples, which were cut from the longest available core pieces (i.e. those less likely to have been accidentally inverted) with the most uniform and undisturbed lithologies. The average stratigraphic sampling interval was about $2 \mathrm{~m}$.

The natural remanent magnetization (NRM) of $\sim 10$ cc specimen cubes cut from each sample was subjected to complete thermal demagnetization to $680^{\circ} \mathrm{C}$ in 10 or more steps for isolation of magnetization components (Fig. 3a-c). IRM acquisition and thermal demagnetization analysis on a representative suite of samples shows that hematite with a maximum unblocking temperature of $680^{\circ} \mathrm{C}$ is the predominant magnetic mineral in the sediments (Fig. 3d). Low to intermediate unblocking temperature components of NRM are evidently some combination of storage, drilling and in situ secondary magnetizations that combine to produce a steeply down inclination that is of limited utility. Of greater significance is a high unblocking temperature magnetization which is more likely to represent acquisition close to the time of deposition. This characteristic remanent magnetization (ChRM) was usually isolated using principal component analysis [25] on five demagnetization steps from $600^{\circ} \mathrm{C}$ to $680^{\circ} \mathrm{C}$ anchored to the origin. Results from four out of 186 samples were rejected due to unstable magnetizations $\left(\mathrm{MAD}>20^{\circ}\right)$. A further six samples were rejected because of steep inclinations $\left(>60^{\circ}\right)$ which are likely to be heavily dominated by a recent magnetic overprint.

The high temperature ChRM component is characterized by a bimodal distribution of relatively shallow directions. The populations of Blomidon samples with positive and negative inclinations are not exactly symmetric: the maximum 
a)

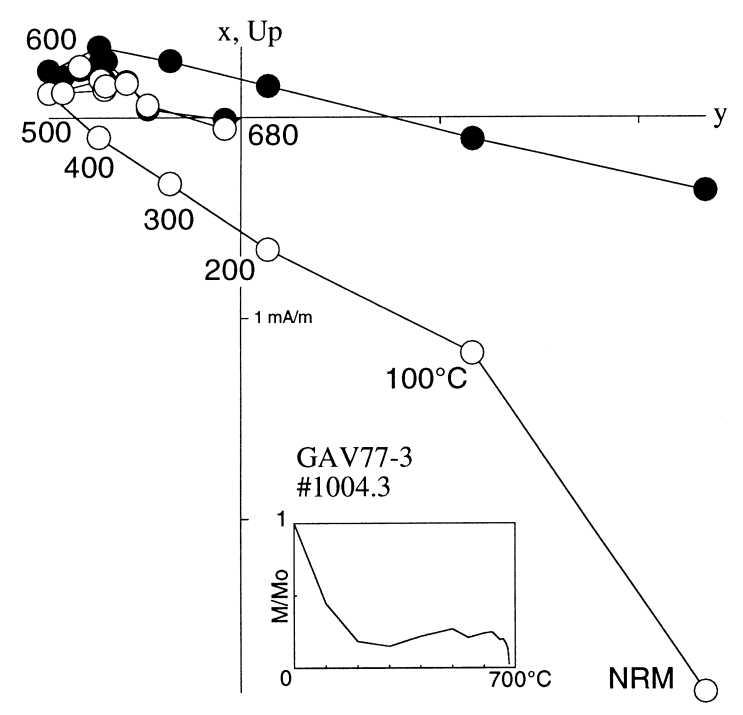

b)

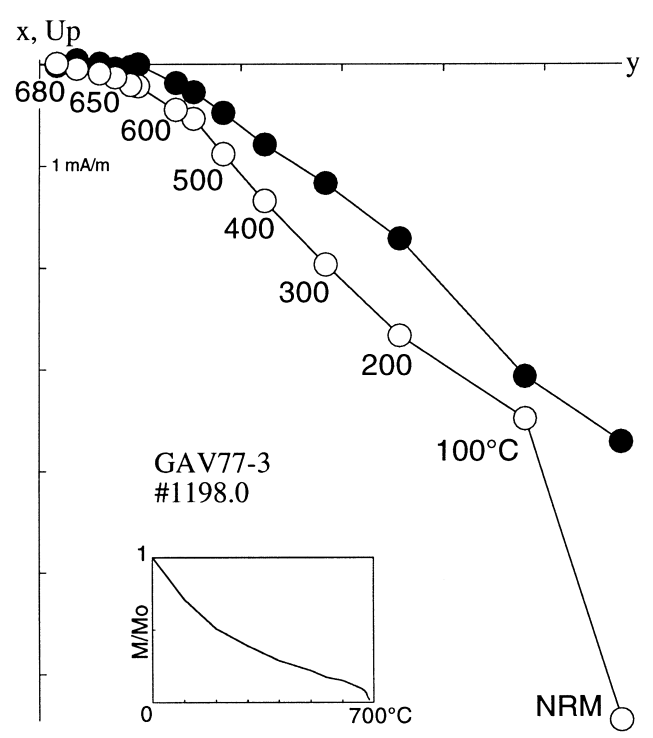

c)

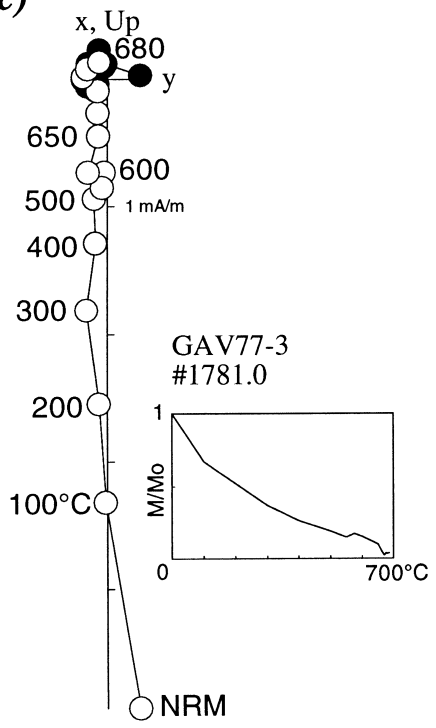

d)

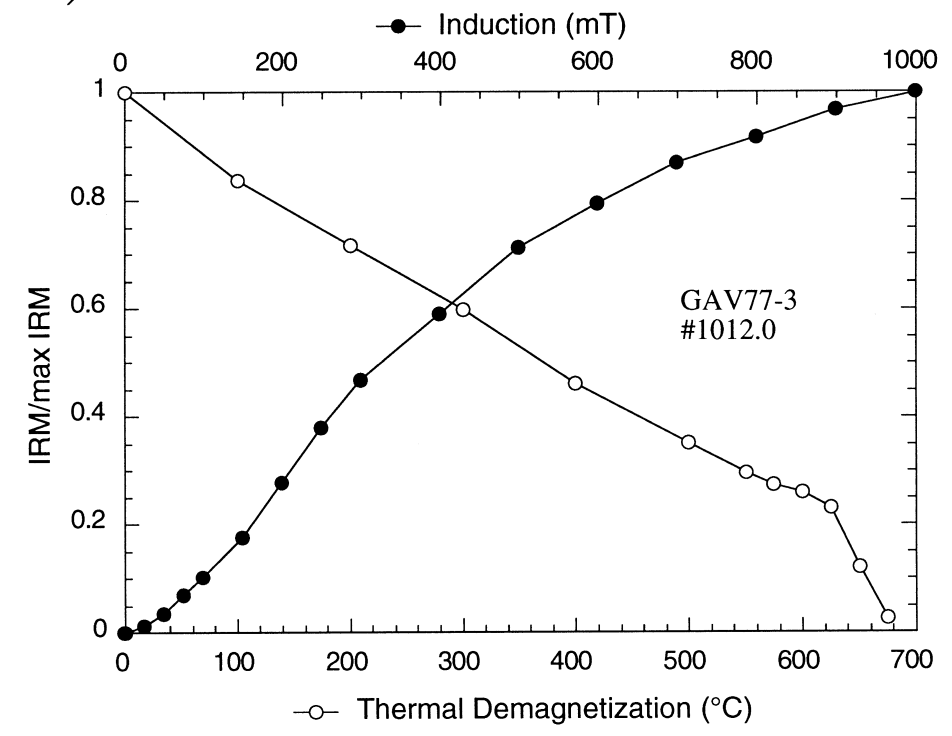

Fig. 3. (a,b,c) Vector end-point diagrams of thermal demagnetization of NRM of representative samples from the GAV-77-3 drill core. Open/closed symbols plotted on vertical/horizontal planes with arbitrary azimuth. Samples in (a) and (b) are from the Blomidon Fm. and are interpreted to have a reverse (a) and normal (b) characteristic magnetization (ChRM). A representative sample (c) from upper Wolfville Formation is dominated by steep overprints and does not yield a characteristic magnetization. (d) Acquisition of IRM and its thermal demagnetization of a representative sample from Blomidon Fm. in GAV-77-3 drill core. Note that saturation IRM is not achieved by 1.0T and that there is a concentration of unblocking temperatures just below $680^{\circ} \mathrm{C}$, features that indicate hematite as the dominant magnetic mineral. Very similar magnetic properties are associated with the Newark Supergroup redbeds in other basins. 
likelihood estimated mean inclination [26] for 76 samples with negative inclinations is $-19.0^{\circ}$ whereas the 107 samples with positive inclinations have a mean of $26.4^{\circ}$. The $7.4^{\circ}$ departure from antiparallel apparently is significant because it exceeds the sum of the $95 \%$ confidence intervals for the normal and reverse polarity directions $\left(6.4^{\circ}\right.$; Table 1). We suggest that the maximum likelihood estimated mean of normal and (inverted) reverse inclinations $\left(23.4 \pm 2.4^{\circ}\right)$ minimizes the bias resulting from residual overprinting that is likely to have caused the asymmetry in directions. This mean inclination corresponds to a paleolatitude of $12.2^{\circ} \mathrm{N}\left(+1.4^{\circ} /-1.3^{\circ}\right)$ for the sampling locality.

Published paleomagnetic data from the Fundy basin are widely dispersed for reasons that are unclear. A reconnaissance study of sedimentary rocks from the Late Triassic lower Fundy Group gave a paleolatitude of only $2^{\circ} \mathrm{N}$ [23], similar to results from $\sim 225 \mathrm{Ma}$ plutons from southern Maine [27]. On the other hand, steeper directions suggesting paleolatitudes close to $30^{\circ} \mathrm{N}$ are typically found in the earliest Jurassic North Mountain Basalt [28]; the three samples of North Mountain Basalt we analyzed from the GAV-773 core have a compatible mean inclination of $52.6^{\circ}$. It is possible that classical inclination error has affected the results from the lower Fundy Group outcrop sediments, tilting has skewed the pluton results, or unaveraged secular variation has biased the North Mountain Basalt directions. In any case, the paleolatitude of $12.2^{\circ} \mathrm{N}$ we obtained for the Blomidon falls within the range of these estimates and, as will be shown below, is in excellent agreement with paleolatitudes from precisely age-correlative rocks in the Newark basin.

The high temperature component reveals a coherent polarity stratigraphy based on downward (=normal) and upward (= reverse) directions (Fig. 4). A strict polarity interpretation of the inclinations should be tempered by the possibility of inverted samples and other sources of ambiguity resulting from the shallow directions and absence of azimuthal control, especially in the case of single-sample polarity intervals. With this caveat in mind, it is nevertheless possible to make a reasonable correlation of the GAV-77-3 magnetostratigraphy to the astronomically tuned geomagnetic polarity time scale (GPTS) from the Newark basin [29] (Fig. 4). Key constraints are: (1) normal polarity of North Mountain Basalt which should correspond to Chron E24n; (2) consistent reverse magnetizations first encountered down-hole at sample level $240 \mathrm{~m}$ which should correspond to Chron E22r or older assuming that the very short E23r subchron would very likely be missed by our sampling; and (3) the $76.5 \mathrm{~m}$ interval of normal polarity between $413.6 \mathrm{~m}$ and $490.1 \mathrm{~m}$ which most likely corresponds to Chron E16n, the longest normal polarity interval in the Norian. These lines of correlation suggest that the GAV-77-3 section extends from the latter part of Chron E15n at $\sim 213.2$ Ma just above the Red Head Member in the lower Blomidon Fm. (magnetozone B11n) to the early part of Chron E24n at $\sim 202$ $\mathrm{Ma}$ in the immediately overlying North Mountain Basalt (magnetozone NM-1n).

An average sedimentation rate of about 27

Table 1

Mean ChRM directions for samples from GAV-77-3 core

\begin{tabular}{lrrrrr}
\hline & $n$ & Inc & mle_Inc & $k$ & a95 \\
\hline Blomidon Fm. & & & & & \\
Normal polarity & 107 & $25.7^{\circ}$ & $26.4^{\circ}$ & 21 & $3.1^{\circ}$ \\
Reverse polarity & 76 & -18.7 & -19.0 & 23 & 3.4 \\
Normal+|Reverse| & 183 & 22.8 & 23.4 & 20 & 2.4 \\
North Mountain Basalt & & & $52.6^{\circ}$ & 275 & $6.5^{\circ}$ \\
Normal polarity & 3 & $52.5^{\circ}$ & \\
\hline
\end{tabular}

$n$ is the number of samples analyzed, Inc is arithmetic mean inclination, mle_Inc is maximum likelihood estimate of mean inclination with associated precision parameter, $k$, and $95 \%$ confidence interval, a95. 


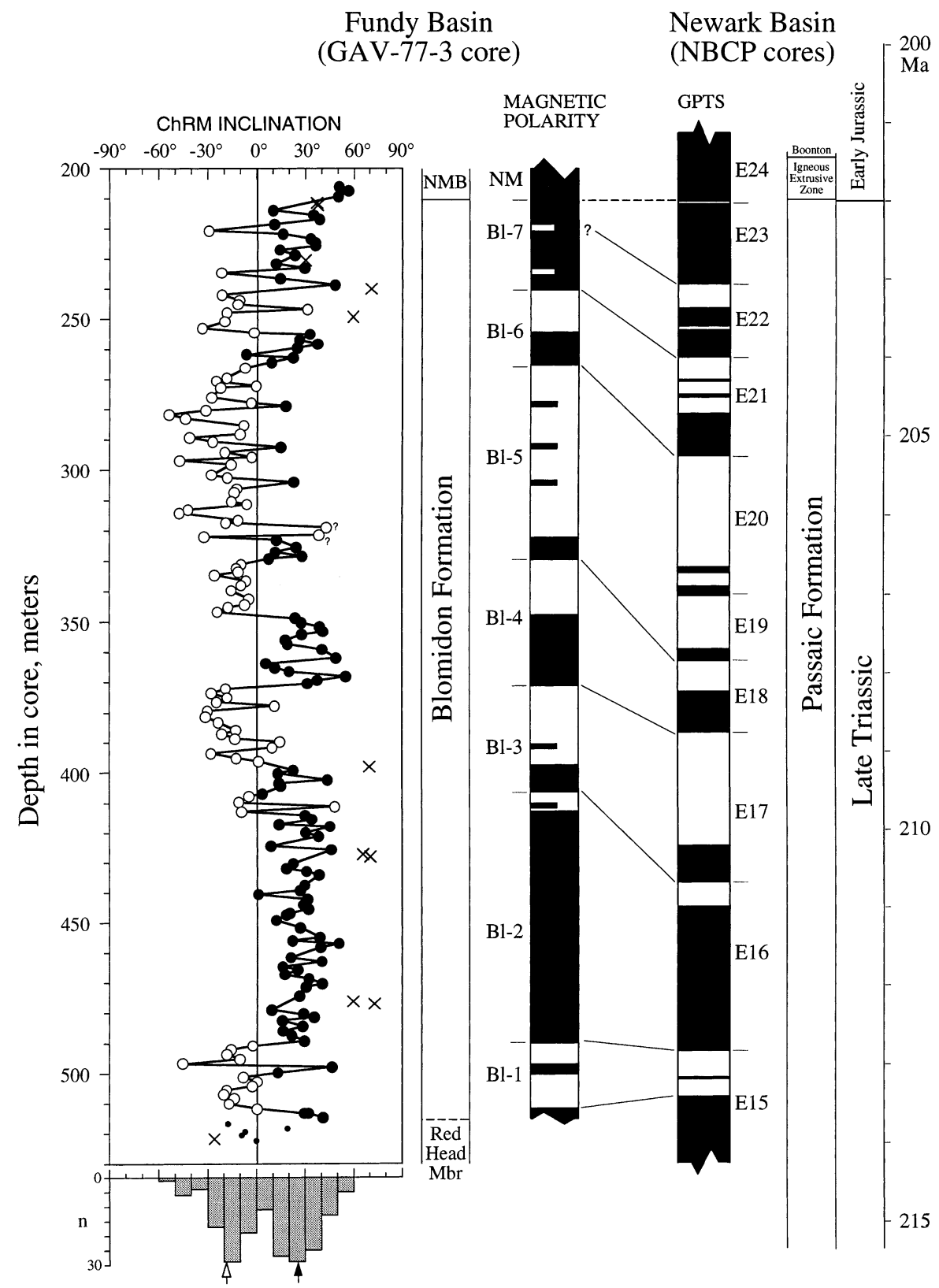

Fig. 4. Magnetostratigraphy of the Blomidon Formation in the GAV-77-3 drill core and correlation to the astronomically calibrated GPTS from the Newark basin [29]. High unblocking temperature ChRM inclinations are used to interpret polarity, positive is considered normal polarity (filled circles) and negative is reverse polarity (open circles, including samples with demagnetization trajectories trending toward reverse polarity but which do not quite achieve a negative inclination before obscured by measurement noise). Histogram of ChRM inclinations includes all measured values except sample data rejected due to unstable magnetizations $\left(\mathrm{MAD}>20^{\circ}\right.$ [25]) or inclinations greater than $60^{\circ}$ that are likely to represent overprinting in more recent times (indicated by x's). Interpretation of polarity is shown by a filled bar for normal, open bar for reverse and half-width bars for single-sample magnetozones. Designations of major normal/reverse polarity magnetozone couplets (prefixed by Bl for Blomidon and NM for North Mountain) follow magnetostratigraphic nomenclature adapted from [15]. 
m/Myr for the $300 \mathrm{~m}$ of cyclical Blomidon Fm., varying from around $42 \mathrm{~m} / \mathrm{Myr}$ in the lower part to only $15 \mathrm{~m} / \mathrm{Myr}$ in the upper part of the unit, is implied by this magnetostratigraphic correlation. The sampling interval and low sedimentation rates contribute to the lack of resolution in differentiating Chrons E22 and E23 in the upper Blomidon Fm. and of delineation of short polarity intervals, such as E23r, in general. We cannot exclude the possibility of unconformities in the sampled section. However, independent biostratigraphic constraints for a Norian age near the basal part of the Blomidon Fm. [20] and a Triassic/Jurassic boundary age in the uppermost Blomidon Fm. [21] suggest that any hiatuses, if present, are not long in duration.

\section{Paleolatitudinal distribution of lithofacies}

The magnetic polarity stratigraphy allows us to place the Fundy section into a precise temporal framework with respect to the Newark and Dan River basin sections. It is evident that the sampled magnetostratigraphic interval from the Fundy ba$\sin$ is younger than and does not overlap with the magnetostratigraphic section from the Dan River basin. However, the Newark basin section encompasses virtually the entire collective stratigraphic range of these rift basins and supplies the overall magnetostratigraphic and paleolatitudinal framework. The resulting spatio-temporal correlation matrix (Fig. 5) for the Newark rift basins documents $10^{\circ}$ of northward drift over $30 \mathrm{Myr}$ of the Late Triassic [15]. Use of locally derived paleomagnetic data avoids problems with projecting paleolatitudes from distant, tectonically rotated localities such as the Colorado Plateau (see Kent and Olsen [16] for discussion).

The Triassic sequence in the Dan River basin, the southernmost rift basin with published paleomagnetic data [16], shows pronounced development of black shales and local coal deposits in the Upper and Lower Cow Branch members of the Leakesville Fm. during the Late Carnian [11]. This is consistent with deposition virtually on the paleoequator as indicated by paleomagnetic results directly $\left(1.8^{\circ} \mathrm{N} \pm 1.9^{\circ} \mathrm{N}\right.$ [16]) as well as those projected from the Newark basin $\left(\sim 1^{\circ} \mathrm{N}\right.$; Fig. 5). Extensive black shales are also developed in the Lockatong Fm. of the Newark basin that were deposited within $5^{\circ}$ north of the paleoequator during the Late Carnian [15]. The succeeding Passaic Fm. shows general evidence of drying [11] as deposition continued during northward drift to almost $10^{\circ} \mathrm{N}$ by the top of the unit.

The sampled interval in the Fundy basin was deposited in more northerly paleolatitudes than the Newark basin and extends the Late Triassic depositional record for eastern North America to about $14^{\circ} \mathrm{N}$ paleolatitude. Virtually no black shales developed in the Fundy basin. However, the eolian dunes in the basal Blomidon Fm. (Red Head Member) as well as small eolian sequences within the cyclical part of the formation [9] were evidently deposited at paleolatitudes of about $10-12^{\circ} \mathrm{N}$ according to projections of Newark paleomagnetic data as well as results from the GAV-77-3 core. Sand patch sedimentary fabrics and halite pseudomorphs in many intervals of the Blomidon Fm. [11], along with one area of eolian sandstones in the McCoy Brook Fm. [18], extend the record of at least intermittent aridity into the Early Jurassic at the Fundy basin locality.

Other Newark rift basins can be placed in this spatio-temporal correlation matrix only approximately pending the availability of detailed magnetostratigraphic data. Nevertheless, it is generally accepted that the black shales and coals in the southern rift basins (e.g. Deep River and Richmond basins) are older than the indicators of more arid conditions in the northern rift basins (e.g. Hartford and Fundy basins) [11,30]. This overall age-dependent facies pattern of drier northward and up-section is consistent with paleolatitudes for the southern rift basins that are more equatorial and, therefore, expected to be initially more humid than for the northern rift basins as eastern North America drifted northward during the Late Triassic.

There are some indications in the northern basins of more humid facies alternating with the arid conditions starting at around the Triassic/Jurassic boundary. Such a change in pattern is not expected from continued slow northward drift but 


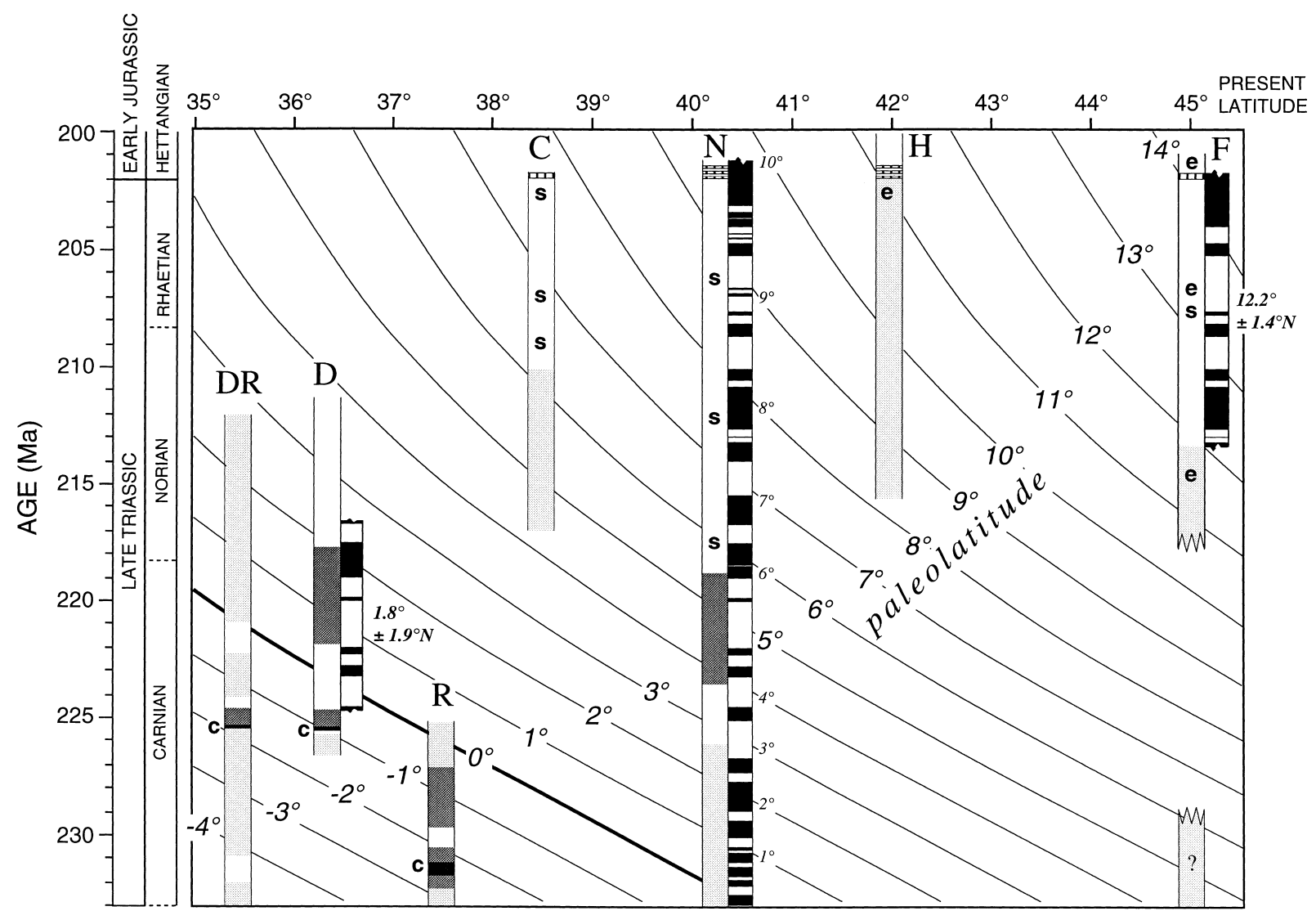

Fig. 5. Paleolatitudinal nomogram (age-geography correlation matrix) for the Late Triassic of eastern North America. Paleolatitude contours are based on the sequence of paleopoles from oriented drill cores in Newark basin [15] and are extended over the transect by taking into account present geographic relationships and a geocentric axial dipole field; $95 \%$ confidence intervals for paleolatitude estimates average $1.3^{\circ}$. The age axis is based on astronomical GPTS from Newark basin [29], which provides the basis for correlation of Dan River basin section [16] and Fundy basin section (this paper). Approximate stratigraphic range is shown for several other Newark rift basin sections (DR, Deep River; R, Richmond; C, Culpeper; H, Hartford; see Fig. 1). In lithology columns, dark stippling shows concentrations of black shales, open is for mainly red lacustrine and playa sediments, and light stippling is for mainly fluvial sediments. Occurrences of other climate-sensitive lithologies [11] are indicated by: c, coals; e, eolian deposits; s, saline minerals.

it could be associated with marine incursions into Pangea as it began to fragment $[8,19]$. Greater tectonic extension and deepening of basins accompanying widespread Central Atlantic Magmatic activity in the Early Jurassic [31,32] may be contributing factors for the facies change. This is suggested by concomitant major increases in sedimentation rate and the continued intermittent presence of eolian sandstones in Jurassic strata of the Fundy basin [18] as well as the Hartford and Pomperaug basins just to the south [33].

\section{Comparison with recent zonal climate indicators}

The sedimentary record from the rift basins of eastern North America demonstrates that the equatorial belt was certainly not arid in the Late Triassic. However, black shales, providing evidence of high humidity, generally developed only within $5^{\circ}$ of the paleoequator whereas eolian dunes and other evidences of aridity are already apparent by $\sim 10^{\circ}$ paleolatitude (Fig. 6a). This implies the existence of a steep latitudinal gradient in the balance between evaporation (E) and pre- 


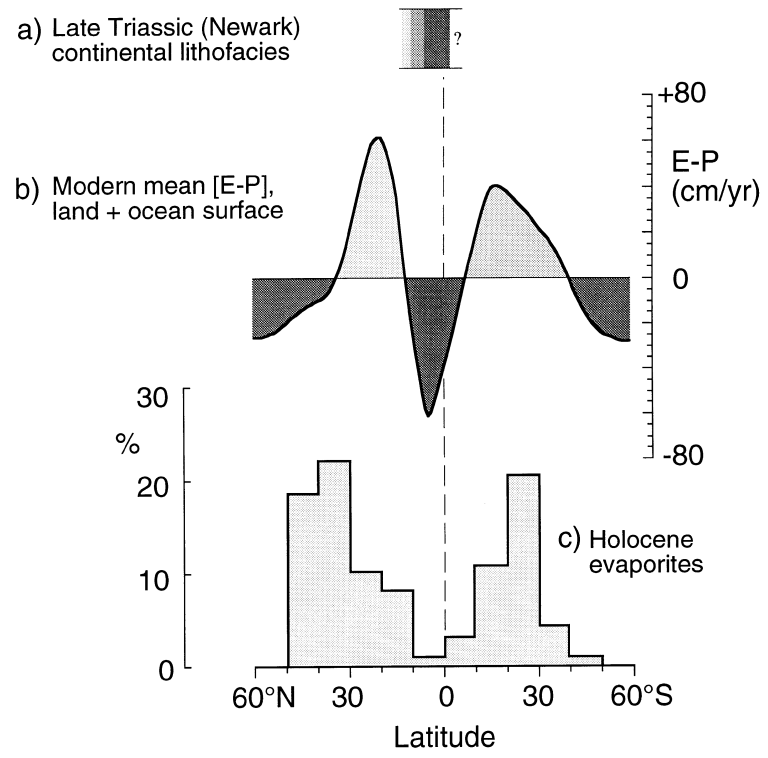

Fig. 6. (a) Paleolatitudinal distribution of black shales (dark stipple) to eolian sandstones (open stipple) from the Late Triassic of eastern North America compared to (b) mean zonal variation in $[\mathrm{E}-\mathrm{P}]$ (evaporation minus precipitation) for the modern 'land+ocean' surface [50] and (c) latitudinal percentage frequency of Holocene evaporite occurrences [34].

cipitation (P). However, the modern mean zonal $\mathrm{E}-\mathrm{P}$ also shows a narrow tropical humid zone with negative $\mathrm{E}-\mathrm{P}$ values very near to the equator and a sharp change to drier conditions with positive $\mathrm{E}-\mathrm{P}$ values within about $10^{\circ}$ of the equator (Fig. 6b). A parallel increase in the occurrence of Holocene evaporites by about $10^{\circ}$ of latitude (Fig. 6c) demonstrates that climate-sensitive rocks can provide a reasonable proxy of $\mathrm{E}-\mathrm{P}$ conditions in modern marine settings [34]. Presumably, climate-sensitive rocks such as coals and eolian sandstones in the Triassic-Jurassic rift basins can also provide suitable proxies of $\mathrm{E}-\mathrm{P}$ conditions in tropical continental environments.

\section{Discussion}

Analyses of early Mesozoic Pangean climate tend to show that it was characterized by a unique phytogeography with an extraordinarily limited tropical humid zone [35]. Some studies even suggest that the tropical rain belt did not exist and the equator was virtually dry $[5,36]$. However, the paleoclimate record summarized here from the Newark rift basins of eastern North America shows clear evidence for the existence of a tropical humid belt within about $5^{\circ}$ of the paleoequator in the Late Triassic. The paleolatitudinal gradient to more arid conditions is indeed steep, judging from the occurrence of eolian dunes by about $10^{\circ}$ paleolatitude. However, neither the steepness of the gradient nor its paleolatitudinal position are especially anomalous when compared to modern zonal patterns.

It is possible that paleotopography intensified and focused monsoonal atmospheric circulation and precipitation patterns over Pangea in the Triassic [37], albeit rather differently than has been suggested for the Late Paleozoic [38]. A principal source of evidence for an anomalously dry equatorial belt in the Late Triassic [3,37] is a carbonate-evaporite sequence of presumed Carnian age penetrated as the oldest rocks in some exploratory wells off the eastern margin of North America [39]. However, given the uncertain age of the evaporites which may be as young as Middle Jurassic [40], we see no compelling reasons to reject the simple hypothesis of a predominantly zonal climate gradient in the tropics of the central part of Pangea in the Late Triassic.

Latitudinal drift of eastern North America in the Late Triassic was only about $0.3^{\circ} / \mathrm{Myr}$ $([15,41]$; but see [42]). The resulting vertical sequence of climate-sensitive facies in individual basins thus tended to change very gradually as the basins drifted slowly across the zonal climate belts. Slow northward drift helps to explain why the southern rift basins tended to have persistent humid facies (e.g. coals and black shales in the Deep River and Dan River basins) whereas the northern rift basins are associated with more arid facies (e.g. evaporites, sand patch fabrics and eolian sandstones in the Fundy basin). The large change in overall sedimentation rates from $\sim 500 \mathrm{~m} / \mathrm{Myr}$ in the southernmost Dan River ba$\sin$ [16], $\sim 200 \mathrm{~m} / \mathrm{Myr}$ in the Newark basin [15] and only $\sim 30 \mathrm{~m} / \mathrm{Myr}$ in the northernmost Fundy basin is in part due to climate-related depositional patterns as well as to different depths of post-rift erosion. 
The modern tropical humid belt is narrow on average and within $\sim 10^{\circ}$ of the equator, whether measured directly from zero crossings of mean zonal $\mathrm{E}-\mathrm{P}$ values (Fig. 6b) or indirectly by climate proxies like the distribution of Holocene evaporites (Fig. 6c). Evidence from the Newark rift basins which takes into account time-transgressive facies due to northward drift suggests that the tropical humid belt was of similar or perhaps slightly narrower width in the Late Triassic (Fig. 6a). This poses a challenge for adequate spatio-temporal resolution in standard compilations of paleoclimate data. For example, even with slow latitudinal drift as in the Late Triassic, the customary mapping of paleoclimate data in 10-15 Myr time slices (e.g. the Carnian or Norian-Rhaetian [3,13]) may obscure evidence for narrow climate zones with steep latitudinal gradients, such as the tropical humid belt. This procedure is equivalent to projecting the occurrence of climate-sensitive facies of different ages according to their present geographic separation (e.g. horizontal axis in Fig. 5) and thereby distorting their paleolatitudinal distribution.

Distortion of climate patterns will be exacerbated in compilations for intervals when latitudinal drift was much faster (e.g. $1 \% / \mathrm{Myr}$ in the Jurassic [43]). In such cases, there is also the greater likelihood of poor age registry and systematic offsets between the paleoclimate indicators and the paleomagnetic observations that are inevitably needed for the paleolatitudinal framework [6]. Artifacts of such cataloging provide a testable alternative explanation to local orographic and monsoonal effects for what are sometimes interpreted as contradictory geographic arrays of climate indicators (e.g. [12]).

In addition to the long-term signal of mean climates across geographic zones, the rift basins also provide an exquisite record of climate change across the full spectrum of orbital or Milankovitch frequencies [44,45]. Milankovitch cyclicity in the Newark basin was used to construct an astronomically tuned GPTS for the Late Triassic [29] that is the basis for precise basin to basin chronostratigraphic correlations. Climate change at Milankovitch frequencies is pervasive and its effects could potentially alias or become confused with the long-term expression of climate if inadequately sampled. The realization of the importance of very long (1.7-2.2 Myr) Milankovitch cycles [45] emphasizes the importance of chronostratigraphic control and correlation in characterizing latitudinal gradients in paleoclimate. This approach already reveals tantalizing evidence of a zonal response to Milankovitch climate change in the Newark rift basins transect. Given the polarity stratigraphy we have established in the Fundy basin and its correlation to the Newark basin, preliminary analysis of sedimentary cycles in the Blomidon $[46,47]$ suggests that the influence of Milankovitch climate forcing at the obliquity ( $\sim 4 \mathrm{kyr}$ ) wavelength at the paleolatitude of the Fundy basin was stronger than further south such as in the Newark and Dan River basins which are dominated by precessional cyclicity $(\sim 20 \mathrm{kyr})$ and its modulation by eccentricity variations $[44,45]$. Climate modeling $[48,49]$ shows that precession-related insolation variations can produce precipitation-evaporation cycles at Milankovitch frequencies across Pangea.

\section{Conclusions}

The Newark rift basins provide a unique latitudinal transect of continental facies that are sensitive to the balance between evaporation and precipitation. These climate-sensitive facies can be precisely correlated across the tropics of Pangea and placed in an independent paleolatitudinal framework using paleomagnetism. Our analysis of the stratigraphic record from the Fundy basin, in conjunction with published data from comparable studies of the more southerly Newark and Dan River basins $[15,16,44]$, leads to these conclusions:

1. The spatio-temporal distribution of Late Triassic paleoclimate indicators from eastern North America shows that evidence of humid conditions (lacustrine black shales and coals) occurs within $5^{\circ}$ of the Late Triassic paleoequator whereas eolian deposits and other evidence of aridity occur by $\sim 10^{\circ}$ of paleolatitude. Therefore, the Late Triassic tropical 
humid belt may have been narrow but, in contrast to many interpretations of low-resolution compilations of climate-sensitive rocks, it was not dry at the paleoequator even in the middle of Pangea.

2. The spatio-temporal distribution of Late Triassic paleoclimate indicators from eastern North America is consistent with a predominantly zonal climate and does not require extraordinary monsoonal or other non-zonal climate mechanisms. Further useful tests of zonal climate would be to obtain climate records from other predicted positions of the paleoequator worldwide as well as from south of the paleoequator to demonstrate hemispheric symmetry.

3. A narrow tropical humid belt with a steep latitudinal moisture gradient inferred for the hothouse world of Late Triassic Pangea is not very different from the latitudinal variation in the balance of evaporation to precipitation of the modern icehouse world of dispersed continents.

4. Continued improvements are needed in the effective spatio-temporal resolution in mapping climate-sensitive facies to separate the effects of a dynamic paleogeography from climate dynamics.

\section{Acknowledgements}

We thank Rob Raeside of Acadia University for giving us free access to the GAV-77-3 core, John McMullin of the Nova Scotia Natural Resources, Minerals and Energy Branch for providing much useful information on the core, Gilberto Mello for technical support in the paleomagnetic laboratory, and Dave Symons and Tom Crowley for constructive reviews of the manuscript. This work was supported by US NSF Grants ATM9317227 and EAR98-04851. LDEO contribution \#6059.[RV]

\section{References}

[1] P.L. Robinson, Palaeoclimatology and continental drift, in: D.H. Tarling and S.K. Runcorn (Eds.), Implications of Continental Drift to the Earth Sciences, Vol. 1, Academic Press, New York, 1973, pp. 451-476.

[2] L.A. Frakes, Climates Throughout Geologic Time, Elsevier Scientific Publishing Company, New York, 1979, 310 pp.

[3] K.M. Wilson, D. Pollard, W.W. Hay, S.L. Thompson and C.N. Wold, General circulation model simulations of Triassic climates: Preliminary Results, in: G.D. Klein (Ed.), Pangea Paleoclimate, Tectonics, and Sedimentation During Accretion, Zenith, and Breakup of a Supercontinent, Geol. Soc. Am. Spec. Pap. 288, Boulder, CO, 1994, pp. 91-116.

[4] J.T. Parrish, A.M. Ziegler, C.R. Scotese, Rainfall patterns and the distribution of coals and evaporites in the Mesozoic and Cenozoic, Palaeogeogr. Palaeoclimatol. Palaeoecol. 40 (1982) 67-101.

[5] J.T. Parrish, Climate of the Supercontinent Pangea, J. Geol. 101 (1993) 2125-2133.

[6] M.A. Chandler, Depiction of modern and Pangean deserts, Evaluation of GCM hydrological diagnostics for paleoclimate studies, Geol. Soc. Am. Spec. Pap. 288 (1994) 117-138.

[7] T.J. Crowley, Pangean climates, Geol. Soc. Am. Spec. Pap. 288 (1994) 25-39.

[8] P.E. Olsen, Stratigraphic record of the Early Mesozoic breakup of Pangea in the Laurasia-Gondwana rift system, Ann. Rev. Earth Planet. Sci. 25 (1997) 337-401.

[9] J.F. Hubert, K.A. Mertz, Eolian dune field of Late Triassic age, Fundy Basin, Nova Scotia Geol. 8 (1980) 516 519.

[10] L.H. Tanner, Formal definition of the Lower Jurassic McCoy Brook Formation, Fundy rift basin, eastern Canada, Atl. Geol. 32 (1996) 127-136.

[11] J.P. Smoot, Sedimentary facies and depositional environments of early Mesozoic Newark Supergroup basins, eastern North America, Paleogeogr. Paleoclimatol. Paleoecol. 84 (1991) 369-423.

[12] W. Manspeizer, Triassic-Liassic basins and climate of the Atlantic passive margins, Geol. Rund. 71 (1982) 895-917.

[13] W.W. Hay, J.F. Behensky Jr., E.J. Barron, J.L.I. Sloan, Late Triassic-Liassic paleoclimatology of the proto-central North Atlantic rift system, Palaeogeogr. Palaeoclimatol. Palaeoecol. 40 (1982) 13-30.

[14] D.V. Kent and P.E. Olsen, Implications of astronomical climate cycles to the chronology of the Triassic, in: G. Bachmann and I. Lerche (Eds.), Epicontinental Triassic, Vol. 3, Zentralblatt fur Geologie und Palaontologie VIII, 2000, pp. 1463-1474.

[15] D.V. Kent, P.E. Olsen, W.K. Witte, Late Triassic-earliest Jurassic geomagnetic polarity sequence and paleolatitudes from drill cores in the Newark rift basin, eastern North America, J. Geophys. Res. 100 (1995) 14965-14998.

[16] D.V. Kent, P.E. Olsen, Paleomagnetism of Upper Triassic continental sedimentary rocks from the Dan River-Danville rift basin (eastern North America), Geol. Soc. Am. Bull. 109 (1997) 366-377. 
[17] J.A. Wade, D.E. Brown, A. Traverse, R.A. Fensome, The Triassic-Jurassic Fundy Basin, Eastern Canada; regional setting, stratigraphy and hydrocarbon potential, Atl. Geol. 32 (1996) 189-231.

[18] J.F. Hubert, K.A. Mertz, Eolian sandstones in Upper Triassic-Lower Jurassic red beds of the Fundy Basin, Nova Scotia, J. Sed. Petrol. 54 (1984) 798-810.

[19] P.E. Olsen, D.V. Kent, S.J. Fowell, R.W. Schlische, M.O. Withjack and P.M. LeTourneau, Implications of a comparison of the stratigraphy and depositional environments of the Argana (Morocco) and Fundy (Nova Scotia, Canada) Permian-Jurassic basins, Proceedings GMPT-2 (2000) (submitted).

[20] H.-D. Sues, P.E. Olsen and D.M. Scott, Cranial Osteology of Hypsognathus fenneri, a latest Triassic procolophonid reptile from the Newark Supergroup of Eastern North America, J. Vert. Paleont. (2000) (in press).

[21] S.J. Fowell, A. Traverse, Palynology and age of the upper Blomidon Formation, Fundy basin, Nova Scotia, Rev. Palaeobot. Palynol. 86 (1995) 211-233.

[22] J.P. Hodych, G.R. Dunning, Did the Manicouagan impact trigger end-of-Triassic mass extinction?, Geology 20 (1992) 51-54.

[23] D.T.A. Symons, R.E. Bormann, R.P. Jans, Paleomagnetism of the Triassic red beds of the lower Fundy Group and Mesozoic tectonism of the Nova Scotia platform, Canada, Tectonophysics 64 (1989) 13-24.

[24] W. Jong, The subsurface lithostratigraphy of the Triassic Blomidon and Upper Wolfville formations (Fundy Basin) of the central Annapolis Valley, Nova Scotia, Ph.D. Thesis, Acadia University, 1985.

[25] J.L. Kirschvink, The least-squares line and plane and the analysis of paleomagnetic data, Geophys. J. R. Astron. Soc. 62 (1980) 699-718.

[26] P.L. McFadden, A.B. Reid, Analysis of palaeomagnetic inclination data, Geophys. J. R. Astron. Soc. 69 (1982) 307-319.

[27] F. Wu, R. VanderVoo, Paleomagnetism of Middle-Late Triassic plutons in southern Maine, Tectonophysics 156 (1988) 51-58.

[28] J.P. Hodych, A. Hayatsu, Paleomagnetism and K-Ar isochron dates of Early Jurassic basaltic flows and dikes of Atlantic Canada, Can. J. Earth Sci. 25 (1988) 1972-1989.

[29] D.V. Kent, P.E. Olsen, Astronomically tuned geomagnetic polarity time scale for the Late Triasssic, J. Geophys. Res. 104 (1999) 12831-12841.

[30] P.E. Olsen and D.V. Kent, High resolution early Mesozoic Pangean climatic transect in lacustrine environments, in: G. Bachmann and I. Lerche (Eds.), Epicontinental Triassic, Vol. 3, Zentralblatt fur Geologie und Palaontologie VIII, 2000, pp. 1475-1496.

[31] J.G. McHone, Broad-terrane Jurassic flood basalts across northeastern North America, Geology 24 (1996) 319-322.

[32] A. Marzoli, P.R. Renne, E.M. Piccirillo, M. Ernesto, G. Gellieni, A. DeMin, Extensive 200-million-year-old continental flood basalts of the Central Atlantic Magmatic Province, Science 284 (1999) 616-618.
[33] P. LeTourneau and P. Huber, Lower Jurassic rift basin eolian strata, Pomperaug Basin, Newark Supergroup, Southbury, CT, Sed. Geol. (in press).

[34] W.A. Gordon, Distribution by latitude of Phanerozoic evaporite deposits, J. Geol. 83 (1975) 671-684.

[35] A.M. Ziegler, J.M. Parrish, J. Yao, E.D. Gyllenhaal, D.B. Rowley, J.T. Parrish, S. Nie, A. Bekker and M.L. Hulver, Early Mesozoic phytogeography and climate, in: J.R.L. Allen, B.J. Hoskins, B.W. Sellwood, R.A. Spicer and P.J. Valdes (Eds.), Palaeoclimates and their Modelling; with Special Reference to the Mesozoic Era, Chapman and Hall, London, 1993, pp. 89-97.

[36] L.A. Frakes, J.E. Francis and J.I. Sykyus, Climate Modes of the Phanerozoic, Cambridge Univ. Press, Cambridge, 1992, 274 pp.

[37] W.W. Hay and C.N. Wold, The role of mountains and plateaus in a Triassic climate model, in: T.J. Crowley and K.C. Burke (Eds.), Tectonic Boundary Conditions for Climate Reconstructions, Oxford Univ. Press, Oxford, 1998, pp. 116-143.

[38] B.L. Otto-Bliesner, Tropical mountains and coal formation: A climate model study of the Westphalian (306 Ma), Geophys. Res. Lett. 20 (1993) 1947-1950.

[39] W. Manspeizer and H.L. Cousminer, Late Triassic-Early Jurassic synrift basins of the U.S. Atlantic margin, in: R.E. Sheriden and J.A. Grow (Eds.), The Geology of North America, 1-2, The Atlantic Continental Margin, Geological Society of America, Boulder, CO, 1988, pp. 197-216.

[40] L.J. Poppe, C.W. Poag, Mesozoic stratigraphy and paleoenvironments of the Georges Bank basin; a correlation of exploratory and COST wells, Mar. Geol. 113 (1993) $147-162$.

[41] D.V. Kent, W.K. Witte, Slow apparent polar wander for North America in the Late Triassic and large Colorado Plateau Rotation, Tectonics 12 (1993) 291-300.

[42] R.S. Molina-Garza, J.W. Geissman, A. Gomez, B. Horton, Paleomagnetic data from Triassic strata, Zuni uplift, New Mexico: Further evidence of large-magnitude Triassic apparent polar wander of North America, J. Geophys. Res. 103 (1998) 24189-24200.

[43] M.C. VanFossen, D.V. Kent, High-latitude paleomagnetic poles from Middle Jurassic plutons and Moat Volcanics in New England and the controversy regarding Jurassic apparent polar wander for North America, J. Geophys. Res. 95 (1990) 17503-17516.

[44] P.E. Olsen, D.V. Kent, Milankovitch climate forcing in the tropics of Pangea during the Late Triassic, Paleogeogr. Paleoclimatol. Paleoecol. 22 (1996) 1-26.

[45] P.E. Olsen, D.V. Kent, Long-period Milankovitch cycles from the Late Triassic and Early Jurassic of eastern North America and their implications for the calibration of the Early Mesozoic time-scale and the long-term behaviour of the planets, Phil. Trans. R. Soc. Lond. Ser. A 357 (1999) 1761-1786.

[46] K.A. Mertz, J.F. Hubert, Cycles of sand-flat sandstone and playa-lacustrine mudstone in the Triassic-Jurassic 
Blomidon redbeds, Fundy rift basin, Nova Scotia: implications for tectonic and climatic controls, Can. J. Earth Sci. 27 (1990) 442-451.

[47] P.E. Olsen and P.J.W. Gore, Tectonic, Depositional, and Paleoecological History of Early Mesozoic Rift Basins, Eastern North America, Field Trip Guidebook T351, Gulf, North Carolina, USA to Parrsboro, Nova Scotia, Canada, July 20-30, 28th Int. Geol. Congress, American Geophysical Union, Washington, DC, 1989.
[48] T.J. Crowley, K.Y. Kim, J.G. Mengel, D.A. Short, Modeling 100000-year climate fluctuations in pre-Pleistocene time series, Science 255 (1992) 705-707.

[49] J.E. Kutzbach, Idealized Pangean climates; sensitivity to orbital change, Geol. Soc. Am. Spec. Pap. 288 (1994) 4155.

[50] T.J. Crowley and G.R. North, Paleoclimatology, Oxford Univ. Press, Oxford, 1991, 349 pp. 